\title{
Neurological symptoms and signs in HTLV-1 patients with overactive bladder syndrome
}

\author{
Sinais e sintomas neurológicos em pacientes com HTLV-1 e síndrome de bexiga hiperativa \\ Davi Tanajura Costaํ, André Luiz Muniz Alves dos Santos ${ }^{1}$, Néviton Matos de Castro ${ }^{1}$, Isadora Cristina de \\ Siqueira', Edgar Marcelino de Carvalho Filho', Marshall Jay Glesby²
}

\begin{abstract}
Objective: To compare neurological symptoms and signs in HTLV-1 asymptomatic carriers and HTLV-1 patients with overactive bladder (OB) syndrome. Methods: We studied $102 \mathrm{HTLV}-1$ positive individuals without HAM/TSP (HTLV-1 associated myelopathy/tropical spastic paraparesis) divided into two groups according to the presence or absence of OB syndrome. Clinical interview, neurological exam and proviral load was performed in all patients. Results and conclusions: Individuals with OB were more commonly female (84.3 vs. $60.8 \%$ of asymptomatics, $\mathrm{p}=0.01$ ). The prevalence of neurological complaints was higher in OB group, especially hand or foot numbness and arm or leg weakness. There was no difference between the groups in neurological strength and reflexes. Weakness complaint remained strongly associated with $\mathrm{OB}$ in multivariate logistic regression analysis adjusting for sex and age [adjusted odds ratio and 95\% $\mathrm{Cl} 3.59$ (1.45-8.88) in arms and 6.68 (2.63-16.93) in legs]. Proviral load was also different between the two groups with higher level on OB individuals.
\end{abstract}

Key words: spinal cord diseases, urinary bladder neurogenic, tropical spastic paraparesis, myelitis.

\section{RESUMO}

Objetivo: Comparar sintomas e sinais neurológicos em pacientes portadores do HTLV-1 assintomáticos e com síndrome de bexiga hiperativa (BH). Métodos: Foram estudados 102 indivíduos com HTLV-1 sem HAM/TSP (mielopatia associada ao HTLV-I/paraparesia espástica tropical), divididos em dois grupos segundo a presença ou ausência de BH. Foram realizados em todos os pacientes entrevista clínica, exame neurológico e carga proviral. Resultados e conclusões: Indivíduos com BH foram na maioria do sexo feminino (84,3 vs. 60,8\% dos assintomáticos, $\mathrm{p}=0,01)$. A prevalência de queixas neurológicas foi maior no grupo $\mathrm{BH}$, especialmente dormências e fraqueza em extremidades. Não houve diferença entre os grupos em relação a achados do exame neurológico. Fraqueza subjetiva permaneceu fortemente associada com BH na regressão logística multivariada ajustada para sexo e idade [OR e IC95\% 3,59 (1,45-8,88) nos braços e 6,68 $(2,63-16,93)$ nas pernas]. A carga proviral foi também diferente entre os dois grupos com nível maior em indivíduos com $\mathrm{BH}$.

Palavras-Chave: doenças da medula espinal, bexiga urinária neurogênica, paraparesia espástica tropical, mielite.

The human T-lymphotropic virus type-1 (HTLV-1) was the first human retrovirus discovered ${ }^{1}$. It causes a highly aggressive T-cell malignancy named adult T-cell leukemia/ lymphoma (ATLL) and a severe chronic neurological disease called HTLV-1 associated myelopathy/tropical spastic paraparesis (HAM/TSP)2. Approximately 20 million people are infected with HTLV-1 worldwide. The endemic areas include tropical zones such as the Caribbean, Equatorial Africa, the Seychelles, Central and South America, and Temperate Zone, especially Southern Japan ${ }^{3}$. In Brazil, one of the highest prevalence is found in Salvador - Bahia with 1.76\% of the population infected ${ }^{4}$.

Investigators have described a spectrum of neurologic disease in HTLV-1 patients, including polyneuropathy, myopathy, neurogenic bladder, cognitive disorders, ALS-like (amyotrophic lateral sclerosis) episodes, meningeal syndromes and cranial neuropathy. The pathogenesis of the neurological manifestations of HTLV-1 infection is poorly understood ${ }^{5}$.

The prevalence of overactive bladder syndrome, a form of neurogenic bladder, has been reported to be approximately

${ }^{1}$ Immunology Department, Bahia Federal University (UFBA), Salvador BA, Brazil;

${ }^{2}$ Weill Cornell Medical College, New York NY, United States of America.

Correspondence: Davi Tanajura; Serviço de Imunologia; Hospital Universitário Professor Edgard Santos; Rua Augusto Viana s/n / 50 andar; $40110-060$

Salvador BA - Brasil; E-mail: davi81@me.com

Conflict of interest: Dr. Tanajura, Dr. Santos, Dr. Castro and Dr. Siqueira report no disclosures.

Dr. Carvalho is funded by NIH grants R01 Al079238-02.

Dr. Glesby is fund by NIH grants R01 079238 and K24 Al078884.

The content of this study is solely responsibility of the authors and does not necessarily represent the official views of the National Institute of Allergy and Infectious Diseases or the National Institutes of Health.

Received 24 April 2011; Received in final form 30 October 2011; Accepted 07 November 2011 
$30 \%$ in HTLV-1 infected individuals without HAM/TSP in Brazil ${ }^{6}$. Some studies concluded that neurogenic bladder is a precursor of HAM/TSP since it represents spinal cord disease and often precedes the clinical manifestation of paraparesis by years ${ }^{7}$.

Our objective was to describe the neurological symptoms and signs in HTLV-1 infected patients without HAM/TSP, stratified on the presence or absence of overactive bladder.

\section{METHODS}

This was a cross-sectional study of 102 patients followed at a cohort in the HTLV multidisciplinary clinic at the Bahia University Hospital (Hospital Universitário Professor Edgard Santos) from June 2004 to December 2010. The population of HTLV-1 infected patients was referred from blood banks, neurology and dermatology clinics in the city of Salvador. The patients enrolled in the study had serological confirmation of HTLV infection by ELISA (Cambridge Biotech Corp., Worcester, MA, USA) and confirmatory Western Blot (WB) analysis (HTLV blot 2.4, Genelab, Singapore).

Subjects were classified by presence or absence of overactive bladder according to the International Continence Society criteria ${ }^{8}$. Specifically, they were considered to have overactive bladder if reported urinary urgency with or without incontinence and usually with nocturia. Urodynamic study was done in patients with overactive bladder syndrome, confirming neurogenic bladder picture and urinary tract infection was ruled out by urine cultures.

The comparison group was composed of 51 randomly selected HTLV-1 patients from the cohort database who did not meet criteria for overactive bladder or HAM/TSP; these subjects were termed "asymptomatics".

\section{Exclusion criteria}

Patients with HTLV-2 or indeterminate WB were excluded from analysis. We also excluded patients with HAM/TSP and comorbid infections (hepatitis B or C, syphilis, HIV and Chagas disease).

All subjects completed a questionnaire with epidemiological, clinical and laboratory data, and were examined by two neurologists (DT and AMS). The participant defined race and ethnicity in this study. Muscular strength was evaluated with the Medical Research Council criteria ${ }^{9}$ as followed: $0=$ no muscular contraction; $1=$ little contraction; 2 =active movement with no gravity; $3=$ active movement against gravity; $4=$ active movement against gravity and resistance; $5=$ normal. Arm and leg strength were evaluated in both sides in proximal and distal muscles. If the score was less than 4 in one muscle, the segment was considered weak for our analysis.

Reflexes were defined according to the Campbell score ${ }^{10}$ in: $0=$ none; 1 =present but diminished; $2=$ normal; $3=$ enhanced; 4=hyperactive, pathological and with clonus. The routinely evaluated reflexes were biceps, triceps, brachioradialis in both arms and patellar and ankle jerks in the legs. Any segment with a reflex graded 3 or 4 was considered abnormal.

All subjects were also assessed by the assisting urologist ( $\mathrm{NC}$ or $\mathrm{PO}$ ) using a semi-structured interview, complete overall and urologic physical examination, and a standardized questionnaire (Urinary Distress Inventory - UDI ${ }^{11}$ ) to determine the occurrence of urinary complaints. All men were assessed for erectile function using the International Index of Erectile Function (IEEF-5) ${ }^{12}$.

We also utilized two scales for evaluation of neurological symptoms: the Expanded Disability Status Scale (EDSS) $)^{13}$ and the Osame Motor Disability Scale (OMDS) ${ }^{14}$.

Proviral load was measured by real time PCR (Real-time TaqMan) in peripheral mononuclear blood cells (PBMCs) as described previously ${ }^{15}$.

Data were analyzed using the STATA statistical software (version 11.1). Mean and standard deviations were calculated for continuous variables and proportions for categorical variables. Student's $t$-test was used to compare continuous variables. Chi-squared test and Fisher's exact test were used for categorical variables as appropriate. Univariate logistic regression was used to calculate odds ratios with $95 \%$ confidence intervals to describe the associations between overactive bladder and clinical characteristics. Similarly, multivariate logistic regression was used to adjust for potential confounders (i.e. age and gender). A p-value of less than 0.05 was used to determine statistical significance.

\section{Ethics}

This study was approved by the Hospital Universitário Professor Edgard Santos Ethical Committee ( $n^{\circ}$ 159/2005) and the Weill Cornell Medical College Institutional Review Board. All participants gave written informed consent.

\section{RESULTS}

We studied 102 HTLV-1 patients, divided into two groups: 51 patients with overactive bladder and 51 asymptomatic patients. Table 1 summarizes the demographic characteristics of the study population. The majority of patients were women, and female gender was associated with overactive bladder [OR (odds ratio) 3.46 (95\%CI 1.35-8.88)]. The mean age of the overactive bladder group was higher than the asymptomatic group, though the difference was not statistically significant ( $46.4 \pm 1.9$ vs. $42.3 \pm 1.7$ years, respectively; $p=0.11)$. Other demographic characteristics were similar between the two groups. The mean EDSS was $0.61 \pm 0.13$ in overactive bladder group and 0 in asymptomatic group $(p<0.01)$, and the OMDS was 0 in both groups by definition. 
Table 2 summarizes the behavioral risk factors and associated conditions among the two study groups. Most of the patients were breastfed and identified themselves as heterosexual. None of the patients had a history of injection drug use, and a few had histories of tattoos. A greater proportion of patients with overactive bladder had histories of transfusion, but this difference was not statistically significant (23.5 vs. $12.0 \%, \mathrm{p}=0.19)$. A history of hypertension was more common in those with overactive bladder (39.2 vs. 15.7\%; OR 3.46, 95\%CI 1.35-8.88), but this was no longer statistically significant after adjustment for age and gender (adjusted OR 1.19, 95\%CI 0.59-8.89). The prevalence of diabetes mellitus, hypothyroidism, smoking and alcohol use were low in both groups, whereas helminthiasis was prevalent in both groups $(61.1 \%$ in overactive bladder vs $40.0 \%$ in asymptomatics, $\mathrm{p}=0.33$ ).

Table 3 summarizes the neurological symptoms and physical exam signs. Several symptoms were more prevalent in the overactive bladder group: hand numbness (OR 3.66, 95\%CI 1.61-8.30), foot numbness (OR 4.09, 95\%CI 1.72-9.71), arm weakness (4.42, 95\%CI 1.56-10.82), leg weakness (OR 8.19, 95\%CI 3.32-20.24) and dry mouth (OR 2.42, 95\%CI 1.01-5.81). All of these symptoms, with the exception of dry mouth, remained statistically significant after adjustment for age and gender. In the objective neurological exam, no differences in arm and length strength or reflexes were noted between the groups.

Table 1. Demographic characteristics of HTLV-l-infected subjects with or without overactive bladder*.

\begin{tabular}{|c|c|c|c|c|c|}
\hline & $\begin{array}{c}\text { OB } \\
(n=51)\end{array}$ & $\begin{array}{l}\text { Asymp } \\
(n=51)\end{array}$ & OR $(95 \% \mathrm{Cl})$ & aOR (95\%Cl) & $\mathrm{p}$-value \\
\hline $\begin{array}{l}\text { Gender } \\
\text { Female } \\
\text { Male }\end{array}$ & $\begin{array}{l}43(84.3) \\
8(15.7)\end{array}$ & $\begin{array}{l}31(60.8) \\
20(39.2)\end{array}$ & $\begin{array}{c}\text { 3.46 }(1.35-8.88) \\
\text { Referent }\end{array}$ & $4.08(1.52-10.94)$ & $0.01^{a}$ \\
\hline Age (years) & $46.4 \pm 1.9$ & $42.3 \pm 1.7$ & $1.02(0.99-1.05)$ & $1.03(1.00-10.6)$ & $0.11^{b}$ \\
\hline $\begin{array}{l}\text { Civil state } \\
\text { Married } \\
\text { Not married }\end{array}$ & $\begin{array}{l}24(47.6) \\
27(52.9)\end{array}$ & $\begin{array}{l}24(47.6) \\
27(52.9)\end{array}$ & $\begin{array}{c}1.00(0.45-2.17) \\
\text { Referent }\end{array}$ & $1.03(0.44-2.41)$ & $1.00^{\circ}$ \\
\hline $\begin{array}{l}\text { Origin } \\
\text { Other cities } \\
\text { Salvador }\end{array}$ & $\begin{array}{l}14(27.4) \\
37(72.6)\end{array}$ & $\begin{array}{c}6(12.0) \\
44(88.0)\end{array}$ & $\begin{array}{c}2.77(0.96-2.74) \\
\text { Referent }\end{array}$ & $2.70(0.89-8.19)$ & $0.07^{a}$ \\
\hline $\begin{array}{l}\text { Ethnicity } \\
\text { Mixed and white } \\
\text { Black }\end{array}$ & $\begin{array}{l}29(60.4) \\
19(39.6)\end{array}$ & $\begin{array}{l}30(58.8) \\
21(41.2)\end{array}$ & $\begin{array}{c}1.06(0.47-2.38) \\
\text { Referent }\end{array}$ & $0.75(0.31-1.82)$ & $0.87^{\circ}$ \\
\hline $\begin{array}{l}\text { Education } \\
\text { Illiterate and primary } \\
\text { High school and college }\end{array}$ & $\begin{array}{l}31(60.8) \\
20(39.2)\end{array}$ & $\begin{array}{l}27(52.9) \\
24(47.1)\end{array}$ & $\begin{array}{c}1.37(0.62-3.02) \\
\text { Referent }\end{array}$ & $1.11(0.47-2.61)$ & $0.42^{\circ}$ \\
\hline $\begin{array}{l}\text { Salary } \\
\text { More than U\$1280/mo } \\
\text { Less than U\$1280/mo }\end{array}$ & $\begin{array}{l}8(16.3) \\
41(83.7)\end{array}$ & $\begin{array}{c}7(13.7) \\
44(86.3)\end{array}$ & $\begin{array}{c}1.22(0.40-3.68) \\
\text { Referent }\end{array}$ & $1.88(0.51-6.86)$ & $0.78^{a}$ \\
\hline
\end{tabular}

Cells represent mean \pm SD or n(\%). OR: odds ratio; aOR: adjusted odds ratio (adjusted for age and gender); Cl: confidence interval; OB: Overactive Bladder Group; Asymp: Asymptomatic Group.

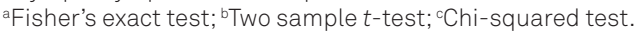

Table 2. Behavioral characteristics, comorbidities and proviral load of HTLV-infected subjects with and without overactive bladder*.

\begin{tabular}{|c|c|c|c|c|c|}
\hline & $\begin{array}{c}\text { OB } \\
(n=51)\end{array}$ & $\begin{array}{l}\text { Asymp } \\
(n=51)\end{array}$ & OR (95\%Cl) & aOR $(95 \% \mathrm{Cl})$ & $p$-value \\
\hline Transfusion & $12(23.5)$ & $6(12.0)$ & $2.25(0.77-6.58)$ & $1.85(0.60-5.67)$ & $0.19^{a}$ \\
\hline Tattoo & 0 & $5(9.8)$ & - & - & $0.06^{a}$ \\
\hline Breastfeeding & $40(97.6)$ & $40(93.0)$ & $0.33(0.03-3.34)$ & $0.25(0.02-2.73)$ & $0.61^{a}$ \\
\hline $\begin{array}{l}\text { Sexual activity } \\
\text { Heterosexual } \\
\text { Homo and bisexual }\end{array}$ & $\begin{array}{c}28(100) \\
0\end{array}$ & $\begin{array}{c}34(91,89) \\
3(8,11)\end{array}$ & - & - & $0.25^{a}$ \\
\hline Injection drug use & 0 & 0 & - & - & - \\
\hline Smoking & $3(9.7)$ & $3(8.8)$ & $1.10(0.20-5.93)$ & $1.10(0.19-6.45)$ & $1.00^{a}$ \\
\hline Alcohol use & $3(8.1)$ & $9(25.0)$ & $0.26(0.06-1.07)$ & $0.35(0.08-1.52)$ & $0.06^{a}$ \\
\hline Diabetes mellitus & $3(5.89)$ & 0 & - & - & $0.24^{a}$ \\
\hline Hypertension & $20(39.2)$ & $8(15.7)$ & $3.46(1.35-8.88)$ & $2.71(0.93-7.82)$ & $0.01^{a}$ \\
\hline Hypothyroidism & $1(2.0)$ & 0 & - & - & $1.00^{a}$ \\
\hline Helminthiasis & $11(61.1)$ & $8(40.0)$ & $2.35(0.64-8.67)$ & $1.19(0.59-8.89)$ & $0.33^{a}$ \\
\hline
\end{tabular}

Cells represent mean \pm SD or n(\%). OR: odds ratio; aOR: adjusted odds ratio (adjusted for age and gender); Cl: confidence interval; OB: Overactive Bladder Group;

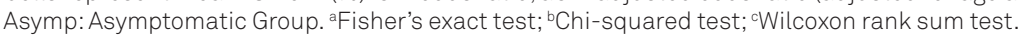


Table 3. Neurological and clinical symptoms and signs in HTLV-1-infected subjects with and without overactive bladder*.

\begin{tabular}{|c|c|c|c|c|c|}
\hline & $\begin{array}{c}\text { OB } \\
(n=48)\end{array}$ & $\begin{array}{l}\text { Asymp } \\
(n=48)\end{array}$ & OR $(95 \% \mathrm{Cl})$ & aOR (95\%Cl) & $p$-value \\
\hline $\begin{array}{l}\text { Paresthesias } \\
\text { Hands } \\
\text { Feet }\end{array}$ & $\begin{array}{l}33(64.7) \\
27(52.9)\end{array}$ & $\begin{array}{l}17(33.3) \\
11(21.6)\end{array}$ & $\begin{array}{l}3.66(1.61-8.30) \\
4.09(1.72-9.71)\end{array}$ & $\begin{array}{l}2.89(1.14-7.33) \\
3.10(1.26-7.64)\end{array}$ & $\begin{array}{l}<0.01^{a} \\
<0.01^{a}\end{array}$ \\
\hline $\begin{array}{l}\text { Self-reported weakness } \\
\text { Arms } \\
\text { Legs }\end{array}$ & $\begin{array}{l}28(54.9) \\
34(66.7)\end{array}$ & $\begin{array}{l}11(21.6) \\
10(19.6)\end{array}$ & $\begin{array}{l}4.42(1.56-10.82) \\
8.19(332-20.24)\end{array}$ & $\begin{array}{c}3.59(1.45-8.88) \\
6.68(2.63-16.93)\end{array}$ & $\begin{array}{l}<0.01^{a} \\
<0.01^{a}\end{array}$ \\
\hline $\begin{array}{l}\text { Dry mouth } \\
\text { Erectile dysfunction (male) }\end{array}$ & $\begin{array}{c}20(40.0) \\
(n=29) \\
2(6.9)\end{array}$ & $\begin{array}{c}11(21.6) \\
(n=27) \\
1(3.7)\end{array}$ & $\begin{array}{l}2.42(1.01-5.81) \\
1.92(0.16-22.54)\end{array}$ & $2.26(0.16-30.98)$ & $0.04^{a}$ \\
\hline $\begin{array}{l}\text { Arm weakness } \\
\text { Right } \\
\text { Left }\end{array}$ & $\begin{array}{l}1(2.08) \\
1(2.08)\end{array}$ & $\begin{array}{l}0 \\
0\end{array}$ & - & $\begin{array}{l}- \\
-\end{array}$ & $\begin{array}{l}1.00^{\mathrm{b}} \\
1.00^{\mathrm{b}}\end{array}$ \\
\hline $\begin{array}{l}\text { Leg weakness } \\
\text { Right proximal } \\
\text { Right distal }\end{array}$ & $\begin{array}{l}4(8.3) \\
4(8.3)\end{array}$ & $\begin{array}{l}0 \\
0\end{array}$ & - & - & $\begin{array}{l}0.11^{b} \\
0.11^{b}\end{array}$ \\
\hline $\begin{array}{l}\text { Abnormal arm reflex } \\
\text { Right } \\
\text { Left }\end{array}$ & $\begin{array}{l}9(18.8) \\
8(16.7)\end{array}$ & $\begin{array}{l}5(10.4) \\
5(10.4)\end{array}$ & $\begin{array}{l}1.98(0.61-6.43) \\
1.05(0.51-5.69)\end{array}$ & $\begin{array}{l}1.28(0.37-4.41) \\
1.07(0.30-3.80)\end{array}$ & $\begin{array}{l}0.38^{b} \\
0.55^{b}\end{array}$ \\
\hline $\begin{array}{l}\text { Abnormal leg reflex } \\
\text { Right } \\
\text { Left }\end{array}$ & $\begin{array}{l}8(16.7) \\
8(16.7)\end{array}$ & $\begin{array}{l}8(16.7) \\
8(16.7)\end{array}$ & $\begin{array}{l}1.00(0.34-2.92) \\
1.00(0.34-2.92)\end{array}$ & $\begin{array}{l}0.70(0.22-2.18) \\
1.00(0.34-2.92)\end{array}$ & $\begin{array}{l}1.00^{b} \\
1,00^{b}\end{array}$ \\
\hline
\end{tabular}

Cells represent mean \pm SD or $\mathrm{n}(\%)$. OR: odds ratio; aOR: adjusted odds ratio (adjusted for age and gender); Cl: confidence interval; OB: Overactive; ${ }^{2} \mathrm{Chi}-\mathrm{squared}$ test; 'bisher's exact test.

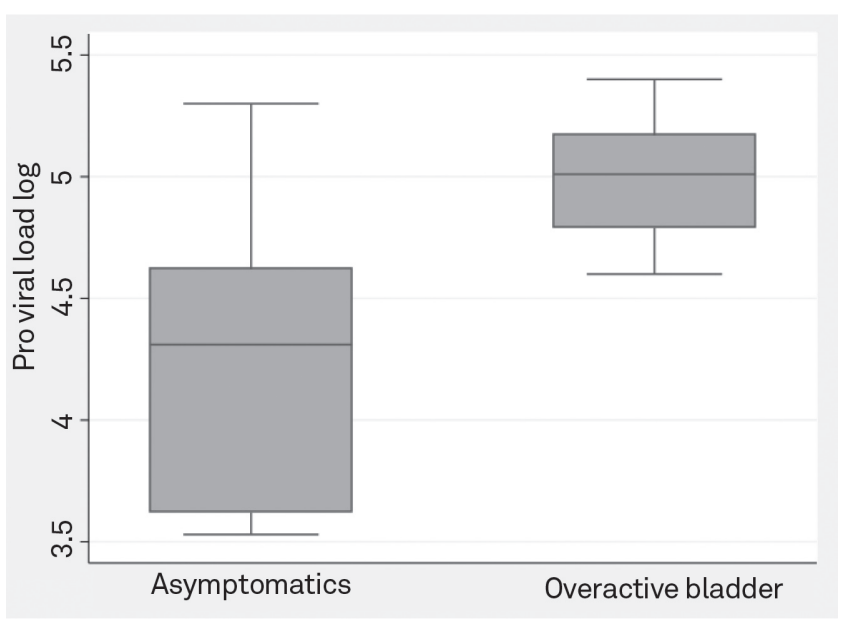

Bladder Group; Asymp: Asymptomatic Group.

Statistical analysis done by Wilcoxon sum test and $p<0.01$.

Figure. Proviral load logarithm representation between the two groups.

Proviral load was measured in 20 patients (10 in each group). Results for asymptomatics were $4.24 \pm 0.63$ copies $/ 10^{6}$ PBMC, and for OB group 5.01 \pm 0.25 copies $/ 10^{6}$ PBMC. Statistical difference was found between the groups as showed in Figure.

\section{DISCUSSION}

In this cross-sectional study of HTLV-1 infected patients without HAM/TSP, we found a higher prevalence of neurological complaints in patients who met criteria for overactive bladder compared to those who did not. Specifically, patients with overactive bladder more commonly reported numbness and weakness of the arms and legs. Objective neurologic findings, however, did not differ between the two groups.

Several prior studies have evaluated neurological signs and symptoms in HTLV-1 patients without HAM/TSP without a specific focus on overactive bladder. In a prospective cohort study with average follow-up of over 10 years, Biswas and colleagues ${ }^{16}$ compared groups of HTLV-1 and HTLV-2 infected subjects without HAM/TSP to seronegative controls and found a broad spectrum of neurologic symptoms and signs that were more prevalent among the HTLV infected subjects. The HTLV-1 group specifically had higher prevalence of leg weakness, impaired tandem gait, Babinski sign, impaired vibration sense and urinary incontinence ${ }^{16}$.

Zunt et al. ${ }^{17}$ found that HTLV-1-infected female commercial sex workers had greater values on quantitative spasticity assessment than seronegative controls despite having a similar prevalence of neurologic symptoms. Specifically, among the 32 HTLV-1 infected women, 13\% complained of walking difficulty, $25 \%$ reported weakness, $16 \%$ bladder incontinence and $3 \%$ had abnormal reflexes.

Another study that evaluated 335 HTLV-1 patients without HAM/TSP found that $13.4 \%$ had symptoms and/or signs of peripheral neuropathy (hypoesthesia, burning sensations, paresthesia or hyperesthesia) ${ }^{18}$. In contrast, our study found a higher prevalence of sensory symptoms especially in the overactive bladder group, in which over half of subjects reported paresthesias in the hands or feet.

Caskey et al. ${ }^{19}$ described clinical and neurological complaints in patients with HTLV-1 without HAM/TSP compared to health blood donors. In this study, HTLV-1 infected subjects 
were more likely to report arm or leg weakness, hand or foot numbness, arthralgia, nocturia, erectile dysfunction, gingivitis, periodontitis and dry oral mucosa. In a subanalysis, HTLV-1 infected subjects with urological symptoms more commonly reported other neurological symptoms, whereas HTLV-1 negative controls with urinary symptoms were not more likely to report other symptoms.

The pathogenesis of neurologic disease in HTLV-1 infection is not well understood, though higher HTLV-1 proviral loads are associated with $\mathrm{HAM} / \mathrm{TSP}^{20}$ and correlated with progression of motor dysfunction in this setting ${ }^{21}$. Of note, Silva and colleagues found that HTLV-1-infected individuals with neurological abnormalities other than HAM/TSP (including isolated neurogenic bladder) had significantly higher proviral loads compared to HTLV-1 asymptomatic individu$a^{22}$. Longitudinal studies are needed to clarify the potential predictive value of proviral load in patients with overactive bladder with respect to future risk of HAM/TSP.
Our study has several noteworthy limitations, including its cross-sectional design and relatively small sample size. Clinicians were not blinded to whether subjects had overactive bladder syndrome, which may have introduced bias in the assessments. Lastly, the definition of overactive bladder was based on self-reported symptoms alone. Any misclassification of patient status, however, would have biased the study towards not finding differences between groups.

Taken together, our data and those of others suggest that HTLV-I infection is associated with a wide spectrum of neurological dysfunction and that HAM/TSP is only the "tip of the iceberg"5. In particular, patients with symptoms of overactive bladder tend to have more neurologic complaints and should be monitored carefully for progression of neurologic disease. Further longitudinal studies are needed to elucidate the natural history of neurological dysfunction in HTLV-1 patients with overactive bladder.

\section{References}

1. Poiesz BJ, Ruscetti FW, Reitz MS, Kalyanaraman VS, Gallo RC. Isolation of a new type $\mathrm{C}$ retrovirus (HTLV) in primary uncultured cells of a patient with Sézary T-cell leukaemia. Nature 1981;294:268-271.

2. Gessain A, Barin F, Vernant JC, et al. Antibodies to human T-lymphotropic virus type-I in patients with tropical spastic paraparesis. Lancet 1985;2:407-410

3. Nakamura T. HTLV-l-associated myelopathy/tropical spastic paraparesis (HAM/TSP): the role of HTLV-I-infected Th1 cells in the pathogenesis, and therapeutic strategy. Folia Neuropathol 2009;47:182-194.

4. Dourado I, Alcantara LCJ, Barreto ML, da Gloria Teixeira M, GalvãoCastro B. HTLV-I in the general population of Salvador, Brazil: a city with African ethnic and sociodemographic characteristics. J Acquir Immune Defic Syndr 2003;34:527-531.

5. Araújo AQC, Leite ACC, Lima MASD, Silva MTT. HTLV-1 and neurological conditions: when to suspect and when to order a diagnostic test for HTLV-1 infection? Arq Neuropsiquiatr 2009;67:132-138.

6. Oliveira P, Castro NM de, Carvalho EM. Urinary and sexual manifestations of patients infected by HTLV-I. Clinics 2007;62: 191-196.

7. Castro NM, Freitas DM, Rodrigues W, Muniz A, Oliveira P, Carvalho EM. Urodynamic features of the voiding dysfunction in HTLV-1 infected individuals. Int Braz J Urol 2007;33:238-245.

8. Abrams P, Cardozo L, Fall M, et al. The standardisation of terminology of lower urinary tract function: report from the Standardisation Subcommittee of the International Continence Society. Neurourol Urodyn 2002;21:167-178.

9. Medical Research Council. Aids to examination of the peripheral nervous system. London: Memorandum no. 45. London: Her Majestry's Stationary Office; 1976.

10. Campbell W. DeJong's The Neurologic Examination. 6th ed. Philadelphia: Lippincott Williams \& Wilkins; 2005.

11. Shumaker SA, Wyman JF, Uebersax JS, McClish D, Fantl JA. Healthrelated quality of life measures for women with urinary incontinence: the Incontinence Impact Questionnaire and the Urogenital Distress Inventory. Continence Program in Women (CPW) Research Group. Qual Life Res 1994;3:291-306.
12. Rosen RC, Cappelleri JC, Smith MD, Lipsky J, Peña BM. Development and evaluation of an abridged, 5-item version of the International Index of Erectile Function (IIEF-5) as a diagnostic tool for erectile dysfunction. Int J Impot Res 1999;11:319-326.

13. Kurtzke JF. Rating neurologic impairment in multiple sclerosis: an expanded disability status scale (EDSS). Neurology 1983;33: 1444-1452.

14. Nakagawa M, Nakahara K, Maruyama Y, et al. Therapeutic trials in 200 patients with HTLV-I-associated myelopathy/tropical spastic paraparesis. J Neurovirol 1996;2:345-355.

15. Dehée A, Césaire R, Désiré N, et al. Quantitation of HTLV-I proviral load by a TaqMan real-time PCR assay. J Virol Methods 2002;102:37-51.

16. Biswas HH, Engstrom JW, Kaidarova Z, et al. Neurologic abnormalities in HTLV-I- and HTLV-II-infected individuals without overt myelopathy. Neurology 2009;73:781-789.

17. Zunt JR, Alarcón JO, Montano S, Longstreth WT, Price R, Holmes KK. Quantitative assessment of subclinical spasticity in human T-cell lymphotropic virus type I infection. Neurology 1999;53:386-390.

18. Leite AC, Silva MT, Alamy AH, et al. Peripheral neuropathy in HTLV-I infected individuals without tropical spastic paraparesis/HTLV-Iassociated myelopathy. J Neurol 2004;251:877-881.

19. Caskey MF, Morgan DJ, Porto AF, et al. Clinical manifestations associated with HTLV type I infection: a cross-sectional study. AIDS Res Hum Retroviruses 2007; 23:365-371.

20. Nagai M, Usuku K, Matsumoto W, et al. Analysis of HTLV-I proviral load in 202 HAM/TSP patients and 243 asymptomatic HTLV-I carriers: high proviral load strongly predisposes to HAM/TSP. J Neurovirol 1998;4:586-593

21. Matsuzaki T, Nakagawa M, Nagai M, et al. HTLV-I proviral load correlates with progression of motor disability in HAM/TSP: analysis of $239 \mathrm{HAM} / \mathrm{TSP}$ patients including 64 patients followed up for 10 years. J Neurovirol 2001;7:228-234.

22. Silva MTT, Harab RC, Leite AC, Schor D, Araújo A, Andrada-Serpa MJ. Human T lymphotropic virus type 1 (HTLV-1) proviral load in asymptomatic carriers, HTLV-1-associated myelopathy/tropical spastic paraparesis, and other neurological abnormalities associated with HTLV-1 infection. Clin Infect Dis 2007;44:689-692. 